\title{
Insect Crude Thoraxial Antigen-G Extracted from Apis mellifera to Enhance Serum Immunoglobulin of Goats: An Entomology Contribution in Animal Science
}

\author{
Wisje Lusia Toar $^{1 *}$, Laurentius Rumokoy ${ }^{1.2}$, Ivonne Maria Untu ${ }^{1}$, Geertruida Assa ${ }^{1}$, \\ ${ }^{1}$ Study Program of Animal Sciences. Faculty of Animal Husbandry, Sam Ratulangi University. Jalan Kampus Unsrat, \\ Manado 95115, Indonesia \\ 2Entomology Program, Postgraduate School. Sam Ratulangi University. Jalan Kampus Unsrat, Manado 95115, Indonesia \\ *Corresponding author email: wisje_toar@live.com
}

\begin{abstract}
This research was conducted to evaluate the influence of insect crude thoraxial antigen-G (CTA) extracted from Apis mellifera L. (Hymenoptera: Apidae) to enhance goat's serum immunoglobulin level. The first part of this study was the determination of insect CTA proportion level. The insects were collected from four different places: Tomohon, Minahasa, North-Minahasa and Manado areas. The second part of the study was the application of $A$. mellifera CTA substance on serum immunoglobulin level classification. In this part, twelve young goats handled with traditional maintenance. The animals experiment were divided in two groups: control group and the other treated with $100 \mu \mathrm{g}$ CTA extract. The proportion of serum immunoglobulins level of goats was detected at $14^{\text {th }}$ days after immunization with insects CTA extract and compared with the animals immunoglobulin levels at the starting day of treatment. The data of CTA extract proportion level of the insects collected were subjected to statistically analysis using the general linear model (GLM) procedure of SPSS 22. Concerning the classification level of the animal treated with CTA was statistically analyzed according to Mann-Whitney test. The results showed that the proportion level of thoraxial antigens-G of $A$. mellifera from all areas observed were not significant different $(P>0.05)$. This crude thoraxial antigens-G of this insect were able to increase serum antibody level of the experiment animal after 14 days of immunization. The immunoglobulin level qualification of animals in treated group were significant higher $(\mathrm{P}<0.05)$ than in control group. We concluded that the CTA extract of the Apis mellifera could be empowered to improve the young goat immunity against the pathogenic microbes in their environment.
\end{abstract}

Key words: insect, crude antigen extract, immunoglobulin

Abstrak: Penelitian ini dilaksanakan untuk mempelajari pengaruh antigen-G toraksial kasar (ATK) yang diekstrak dari Apis mellifera $L$ (Hymenoptera: Apidae) untuk memacu tingkat immunoglobulin serum kambing. Bagian pertama dari penelitian ini yaitu mendeterminasi proporsi level ATK serangga. Serangga-serangga yang dikoleksi berasal dari empat tempat berbeda yaitu di area sekitar Tomohon, Minahasa, Minahasa Utara dan Manado. Bagian kedua adalah penerapan substansi ekstrak ATK A. mellifera terhadap klasifikasi proporsi tingkat immunoglobulin kambing. Pada bagian ini digunakan dua belas kambing muda yang dipelihara secara tradisional. Hewan-hewan eksperimen dibagi dalam dua kelompok yaitu kelompok kontrol dan kelompok perlakuan dengan $100 \mu \mathrm{g}$ ATK extract. Klasifikasi proporsi tingkat immunoglobulin serum kambing dideteksi pada hari pertama sebelum imunisasi dan dibandingkan hasilnya dengan deteksi yang dilakukan pada hari ke 14 setelah imunisasi ekstrak ATK. Data proporsi level ATK ekstrak dari serangga-serangga yang dikoleksi dianalisis secara statistic menggunakan general linear model (GLM) mengikuti prosedur SPSS 22. Sedangkan analisis data menyangkut klasifikasi proporsi level immunoglobulin serum menggunakan uji Mann-Whitney. Hasil penelitian menunjukkan bahwa proporsi level antigen-G toraksial kasar $A$. mellifera dari berbagai area tidak berbeda secara nyata $(P>0.05)$. Ekstrak kasar antigen- $G$ toraksial ini mampu meningkatkan level antibodi serum hewan-hewan eksperimen yang dideteksi pada hari ke 14 setelah diimunisasi. Klasifikasi kualitas proporsi level imunoglobulin dari hewan-hewan yang diberi perlakuan berbeda nyata $(P<0.05)$ dibandingkan pada hewan-hewan kontrol. Kesimpulan dari penelitian ini adalah eskrak ATK A. mellifera dapat didayagunakan untuk meningkatkan imunias kambing muda menghadapi mikroba-mikroba patogen di lingkungannya.

Kata kunci: serangga, antigen ekstrak kasar, imunoglobulin 


\section{Introduction}

Nowadays entomology contributes a significant positive impact to the animal husbandry efforts. The potential of insect antigens to enhance the immune system of ruminants has attracted the scientists today. Ameri et al. (2008) showed that the substances of crude saliva gland extract of Stomoxys calcitrans were significantly improved the cow's antibodies, although this sucking insect paradoxically could be an important transmitter of many pathogenic microbes to the ruminants and some other mammals. Toar et al. (2017) evaluated the empowerment of crude extract antigen-G of Bombyx mori on goats immunity which caused a significant different of serum $\lg G$ of this animals.

If the animal's life exists in the environment condition with a high risk of pathogenic agent contamination, then this application of antigenic substances extracted from insect could be an alternative solution.

The mortality of goats after parturition could be appeared as a consequence of virus, pathogen bacteria and parasites (Komatsu et al., 2009). Rumokoy and Toar (2014) reported that the failure of passive transfer of immunoglobulin could cause a severe health problem to the new born. The use of commercial colostrum IgG is relatively expensive in small-scale farm and therefore it is important to look for another alternative solution, for example by using insect antigen substance extracted from Bombyx mori (Toar et al., 2017).

\section{Materials and Method}

\section{Insect collection}

The insects of $A$. mellifera have collected an insect sweep net, after capturing the insect then placed in a glass bottle which aerated by using a perforated cap and equipped with cotton at the bottom to ensure the bees could move freely and survive inside the bottle before entering the next steps. The collections were done in the different agriculture areas as follow: North Minahasa, Minahasa, Tomohon and Manado.

\section{Crude Thoraxial Antigen Preparation}

Euthanasia of the insect was done at $-4{ }^{\circ} \mathrm{C}$. The isolation of CTA was realized at a room temperature to get the thoracic gland which performed carefully using tweezers on a petri dish to avoid the other substances originated from insect's body. The thoracic gland was demolished then added with sterile water and filtered. After that the substance obtained was centrifuged at $1500 \mathrm{rpm}$ for 1 minute, then the floating surface part was removed and the bottom suspension was taken with a pipette and mixed with $0.5 \mathrm{ml}$ of sterile distilled water before passing through portable refractometer to get the CTA proportion by $\mathrm{Brx}$ index. The crude extract of thoraxic antigen was frozen in the refrigerator before applying in the experiment.

\section{Experiment Animal}

Twelve samples of local breed young goats were used under traditional handling in Sentrum Agraris Lotta (SAL) in Pineleng Minahasa where these animals get their own food by selecting and grazing from a variety of forage around the agricultural area. To avoid direct contact with cultivated plants, these animals were set so that they could not interfered with other plants such as vegetables. The drinking water was distributed in ad libitum. No other special treatment was given to the animal such as concentrates, feed supplements nor other medical substances.

\section{Immunization Treatment by Injection and IgG Detection}

The parameter measured was the quality proportion level of immunoglobulin serum of the goats. The treatment was $100 \mu \mathrm{g}$ of CTA extract by subcutaneous injection per animal. Two moments of IgG level were measured at 
the first day of experiment and at the fourteenth days after the immunization.

\section{Data Analysis}

The data of CTA extract proportion level of the insects collected were statistically analyzed by using the general linear model (GLM) procedure of SPSS 22, while the quality classification level of serum immunoglobulin of animal treated with CTA was statistically analyzed according to Mann-Whitney test (Zar, 1996).

\section{Results and Discussion}

The measurements of proximate value proportion of CTA of $A$. mellifera from all observed areas attainted $>60 \mathrm{mg} / \mathrm{dL}(>23 \%$ brx). The analysis of variance showed a nonsignificance value $(P>0.05)$ between each sample indicated that the antigen-G composition level of samples from this locations was the same qualification.

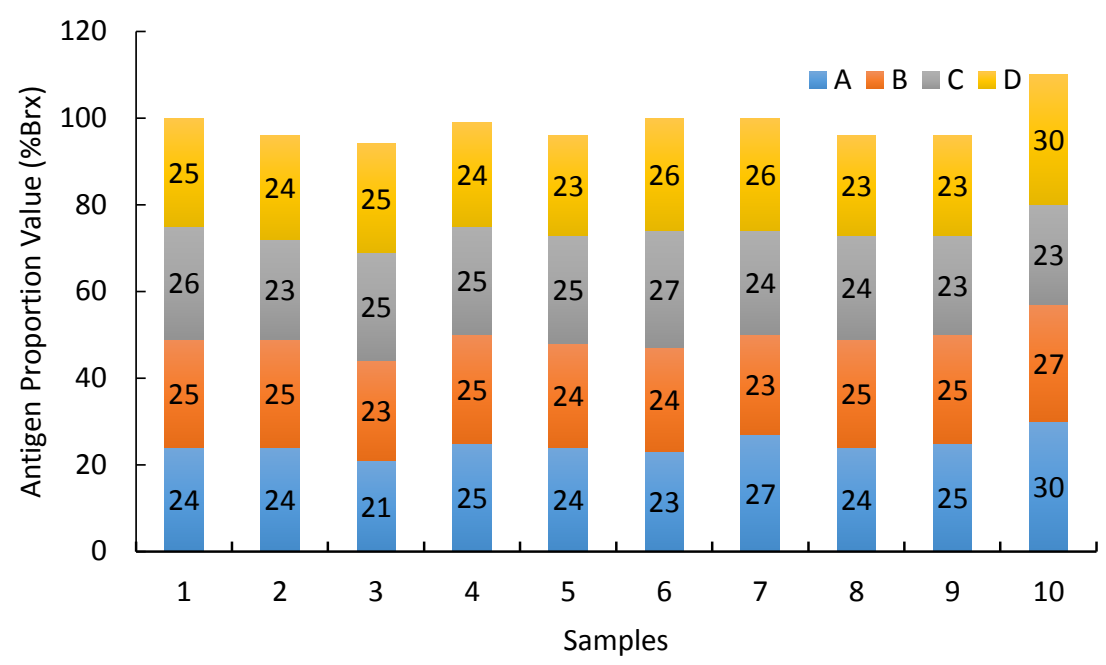

Figure 1. Crude Thoraxial Antigen (CTA) proportion value (\% Brx) of Apis mellifera from four location ( $A=$ Tomohon, B=North Minahasa, C=Manado, $D=$ Minahasa)

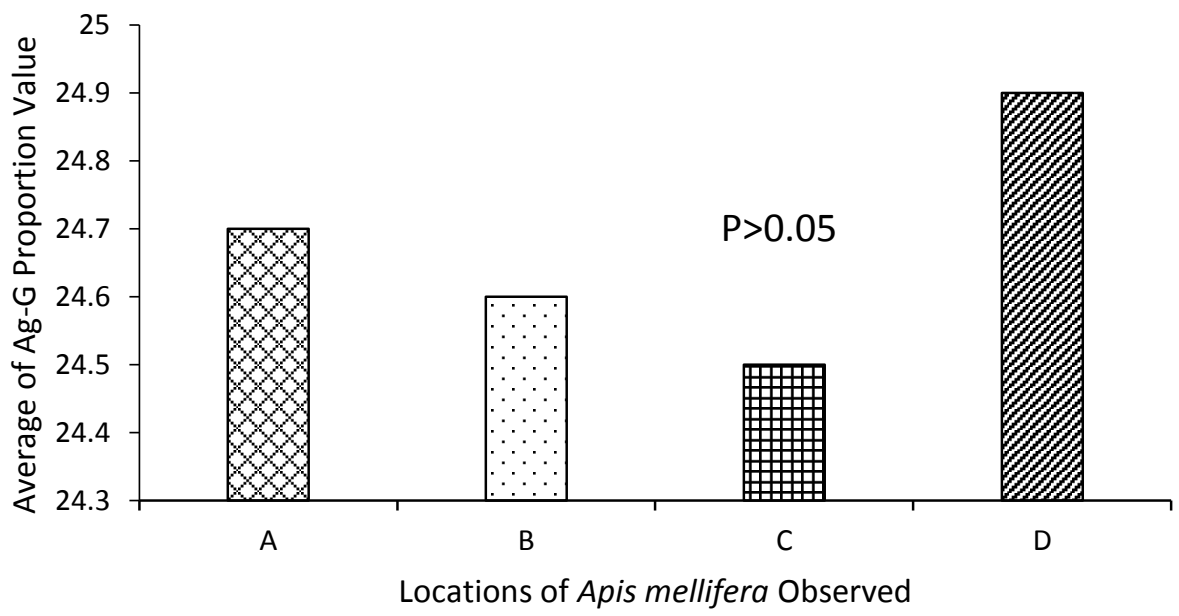

Figure 2. The average of Ag-G Proportion Value of Apis mellifera from four location $(A=T$ Tomohon, $B=$ North Minahasa, $C=$ Manado, $D=$ Minahasa) 


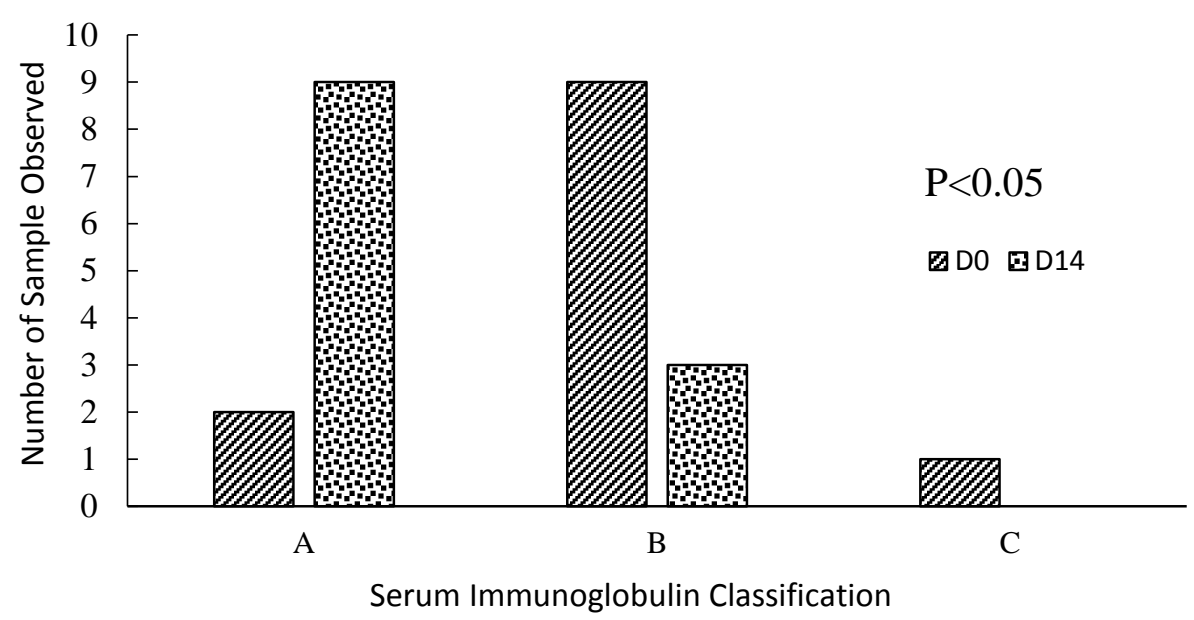

Figure 3. Serum immunoglobulin classification of young goats immunized with antigen-g of $A$. mellifera. Observed at day zero (first day of the immunization) and $14^{\text {th }}$ days after immunization. The blood serum immunoglobulin levels classification were: A (very good), B (good) C (poor).

The Figures ( 1 and 2 ) above showed that the samples $D$ from Tomohon tend to be the highest antigens values ( $24.9 \% \mathrm{brx}$ ), followed by the samples A came from Minahasa (24.7\% brx) and then B selected from North Minahasa Area (24.5\% brx) and the last $C$ slightly decreased to $24.5 \%$ brx. The variation level of its antigen could be related to the behavior of this insect against the environment (Zaitoun et al., 2001). Even though the average of antigen- $G$ level proportions were varied between 24.5 to 24.9 $\%$ according the location but the concentration of antigen protein was superior that $60 \mathrm{mg} \cdot \mathrm{dl}^{-1}$. The data analysis indicated that there has no significant different $(P>0.05)$ between the CTA of $A$. mellifera from several places in North Sulawesi. The similar antigens of saliva gland crude extract of Stomoxys calcitrans have been reported by Ameri et al. (2008) provide a role as immunoglobulin binding protein which was able to enhance the immunity response of cows. This immunity function is related to the study of Obame-Nkoghe et al. (2017) indicated that the animals should enhance its defense of pathogenic agents transmitted by others dipteran.
The treatment with CTA of A. mellifera resulted in a higher level of serum immunoglobulin $(P<0.05)$ of young goats. This performance was described in figure 3 . The $C$ classification (poor level) did not appear at $14^{\text {th }}$ days after CTA immunization could be affected by the immunity response of antigen- $G$ presence in the body of the experiment animals. In other hand it is revealed that the CTA injection up to $100 \mu \mathrm{g}$ has an important role to improve antibodies levels of goats. Even though, it should be mentioned that there are many factors influence the level of immunoglobulin in the serum according to Conley et al. (2000); Agarwal and CunninghamRundles (2007).

This role of CTH as antigen extracted from $A$. mellifera to increase antibodies production in young goats could be linked to the factors innate immunity and vaccine responses in neonates as described by Kampmann and Jones (2015) which were affected by the type of vaccine, timing of vaccination, location, microbiome, co-infections, maternal factors, host genetics and pattern recognition receptors. More over an effort to increase the goat's immunity by antigen combined with 
adjuvant has been performed by lqbal et al. (2016) in young goats: They result showed a positive response to reject the parasite insect in the animal tested by using this combination substances.

The immunity assessment obtained in our study which has a significantly different of immunoglobulin level after $14^{\text {th }}$ days postimmunization could be connected to the results as informed by several researchers. Toar et al. (2017) revealed a function of antigen extracted from insect larva (Bombyx mori) to enhance immunoglobulin level in young goats, while Ameri et al. (2008) reported that the crude saliva extracted from stable fly were able to support the bovine immune-response. Basha et al. (2014) underlined that neonates have little immunological memory and a developing immune system, which increases their vulnerability to infectious agents. The consequence for that is needed to overcome the high risk of pathogenic agent contamination exist in this period of life.

The young animals are susceptible to pathogen microbe especially when the failure of passive transfer is happened (Rumokoy and Toar, 2014) and this condition become important to neonates because they are always vulnerable to the infection (Wilcox et al., 2017) especially when the transfer of immunoglobulin-G from mother to fetus has a difficulty.

\section{Conclusion}

The crude thoraxial antigen (CTA) extracted from Apis mellifera could be used as an alternative solution to improve the young goats defense against pathogenic microbes. This situation is important to the animal immunity system caused the natural hypo-globulinemia after parturition.

\section{References}

Agarwal S, and C Cunningham-Rundles. 2007. Assessment and clinical interpretation of reduced IgG values. Annals Of Allergy Asthma and Immunology. 99(3):281-283.

Ameri $M, X$ Wang, MJ Wilkerson, MR Kanost MR and AB Broce. 2008. An Immunoglobulin Binding Protein (Antigen5) of the Stable Fly Salivary Gland Stimulates Bovine Immune Responses. Journal of Medical Entomology. 45(1):94-101.

Basha S, Surendran N, and M. Pichichero. 2014. Immune Responses in Neonates. Expert Rev Clin Immunol. 10(9):1171-1184.

Conley ME, J Rohrer, Y Minegishi. 2000. X-linked agammaglobulinemia. Clin Rev Allergy Immunol. 19:183-204.

Komatsu N, ME Mariotti-Ferrandiz, Y Wang, B Malissen, H Waldmann and S Hori. 2009. Heterogeneity of natural Foxp3+ $T$ cells: a committed regulatory $\mathrm{T}$-cell lineage and an uncommitted minor population retaining plasticity. In: Proceedings of the National Academy of Sciences of the United States of America. USA 106.pp:1903-1908.

Iqbal A, Asmatullah-Kakar, Mujeebur-Rehman, Iram S, Gul S, MA Panezai. 2016. Analysis of Immune Response in Goats Capra hircus lehri Against Different Doses of Cement Cone Extract Antigen Taken from Ticks (Ixodidae) Emulsified with Different Adjuvants. Pakistan J. Zool. 48(4):11791184.

Kampmann B and CE Jones. 2015. Factors influencing innate immunity and vaccine responses in infancy. Phil. Trans. R. Soc. B 370: 20140148:1-5.

Obame-Nkoghe J, N Rahola, D Ayala, P Yangari, D Jiolle, X Allene, M Bourgarel, GD Maganga, N Berthet, EM Leroy and C Paupy. 2017. Exploring the diversity of blood-sucking Diptera in caves of Central Africa. Sci Rep. 21;7(1):250.

Rumokoy LJM and WL Toar. 2014. The Equine Colostrums of milk treatment against pathogenic agent. Scientific Papers: Series D, Animal ScienceThe International Session of Scientific Communications of the Faculty of Animal Science USAMV. 42:174-177.

Toar WL, Kaunang C, Untu IM, L Rumokoy. 2017. The empowerment of crude extract antigen-G of insect on goats immunity enhancement. An entomology contribution in animal husbandry. Scientific Papers Series D. Animal Science. Vol LX:271-273.

Wilcox CR, Holder B, and CE Jones. 2017. Factors Affecting the FcRn-Mediated Transplacental Transfer of Antibodies and Implications for 
Wisje Lusia Toar, et al/Animal Production. 20(2):133-138, 2018

Accredited by Kemenristek Dikti No 32a/E/KPT/2017. ISSN 1411-2027

Vaccination in Pregnancy. Front Immunol. 8: 1294. doi: 10.3389/fimmu.2017.01294.

Zaitoun ST, A Al-Ghzawi and HK Shannag. 2001. Grooming behavior of Apis mellifera syriaca towards Varroa jacobsoni in Jordan. J. App. Ent. 125:85-87.

Zar JH. 1996. Biostatistic analysis. $3^{\text {rd }}$ edition. Prentice-Hall International, Inc. New Jersey. 